\title{
IMPACT OF MONEY SUPPLY ON SRI LANKAN ECONOMY: AN ECONOMETRIC ANALYSIS
}

\author{
A.L.Mohamed Aslam \\ Sri Lanka Planning Service \\ Ministry of National Policy Planning, \\ Sri Lanka \\ Email: mohamedaslamalm@gmail.com
}

\begin{abstract}
Keywords: Money supply, Economic growth, Exchange Rate, Exports earnings, imports outflow,
\end{abstract} and Colombo Consumer Price Index.

\begin{abstract}
Economists argue that the money supply positively impact on economic growth of nations. In Sri Lankan context this statement was not tested econometrically. Therefore, the aim of this study was to scrutinize the impact of money supply on Sri Lankan economy. To exam this objective, this study considered the time series data from the period of 1959 to 2013 and used two types of variables such as dependent and independent variables. Here, the gross domestic product was considered as dependent variable, and Money supply, Exchange rate, Exports earnings, Imports outflow, the Colombo consumer price index were deemed as independent variables. In the meantime, the multivariate econometric method was used to test the impacts of money supply on economic growth of Sri Lanka. According to the analytical results, the money supply has kept positive impact on the economic growth of Sri Lanka at 1\% significant level. The R- squared of the estimated model was $92 \%$ which was indicated that the estimated model was desirable. Meanwhile, the Durbin Watson test statistic was 2.43 and also the Breusch -Godfrey serial correlation LM test results was greater than $5 \%$. Therefore, these statistics indicated that, the estimated model was not suffering from serial correlation.
\end{abstract}

\section{Introduction}

Money supply plays a crucial role in the determination of price level and interest rate. In the view of economics, the money supply means that the total amount of monetary assets available in an economy at a specific time [3]. The money supply consists of currency with the public and the demand deposits of the public.

As well, economic growth means the percentage increase in Gross Domestic Product (GDP) or Gross National Product (GNP) on the particular year. The economic growth is measured based on the fixed and the market prices [4].

When this study searched the relationship between the money supply and economic growth, it found that there are two different concepts such as Monetarist and Keynesian concepts about the relationship between the money supply and economic growth. According to the Monetarists concept, they argue that the money supply is a boosting instrument to the economic growth. On the other hand, the Keynesians argue that the money supply is very limited influence on the economic growth. However, both concepts agreed that there is a relationship between the money supply and the economic growth [1 and 6].

In Sri Lankan perspectives also, the money supply has influence on the economic growth because the previous government of Sri Lanka has increased the money supply in different manner to promote the sustainable economic growth. They supplied huge amount of paper and coins money through the monetary authority, the Central bank of Sri Lanka. According to the statistics of the Central Bank of Sri Lanka that the money supply was increased to 18\% in 2013 compared with 2012. In the meantime the economic growth of Sri Lanka was increased to $8.2 \%$ in 2013 with compared of 2012. Based on this statistics, this study believes that the money supply has a relationship with the economic growth of Sri Lanka. However, this relationship was not proved econometrically. Therefore, this study is going to examine the relationship between the money 
supply and the economic growth of Sri Lana through econometric techniques. To attain this relationship, this study is designed as background of the study, objective of the study, methodology, results and discussion, finally conclusion and policy recommendations.

\section{Objective of this study}

The objective of this study is to examine the impact of money supply on Sri Lankan economy

\section{Review of literature}

On the relationship between the money supply and the economic growth, this study considers the two types of literatures such as theoretical and empirical views. In the theoretical views, as mentioned earlier the Monetarists and the Keynesians argue that the money supply has positive relationship with the economic growth in different manner. Which theoretical views are explained by the IS- LM and AD- AS aspects. Likewise, Irving Fisher who is an American economist explains the relationship between money supply and economic growth by the exchange equation $\mathrm{MV}=\mathrm{PT}$. Based on these aspects, there are number of empirical studies which were done by the following researchers:

[2] studied the causal relationship among the money growth, inflation, currency devaluation and economic growth in Indonesian context. In his study, the time series data were employed during the period of 1954 to 2002 and the multiple regression method was utilized to test the relationship among the Independent and dependent variables. This study found that there was positive relationship among the dependent and independents variables.

[6] scrutinized the relationship between the money supply and the output of USA. This study found that the money supply helps in the interpretation of output and not the opposite. It means that there was causality relationship from the money supply to gross domestic product. Even as [7] examined the relationship between money supply and gross domestic product of Bahrain using the time series data for the periods of 2000 to 2013. In this study the ADF, the Engel Granger two steps cointegration test, the error correction mechanism were used to examine the relationship between the money supply and the gross domestic product. This study determined that the money supply and the gross domestic product were cointegrated at $1^{\text {st }}$ difference level I(1). And the Granger causality test showed that there was unidirectional relationship from the real gross domestic product to the money supply in the short run as well as the long run periods.

[8] studied the impact of Monetary Variables on Economic Growth in Iran. To test the relationship between these variables, this study used time series data from the period of 1959 to 2008 support of the following variables such as employment, real economic growth, real money volume, real growth rate of government expenses, growth rate of oil revenues and exchange rates. In this study the OLS econometric technique was used to test the relationship between dependent and independent variables. Based on this analysis, this study found that the money volume was not significantly impact on economic growth of Iran. In the meantime, [9] examined the impact of monetary policy on economic growth in Iran. This study used annual time series data during the period of 1974 to 2008. To test the impact of monetary policy the econometric OLS method was employed. At last, this study explored that the money supply was positively impact on economic growth of Iran.

[10] explored the impact of money supply on economic growth on Nigerian economy. The time series data from 1980 to 2006 were utilized to test the impact of money supply. The money supply has positive impact on economic growth at 5\% significant level. In this study the OLS econometric techniques was employed. In accordance with results, even though money supply affects positively on economic growth, but it has no significant impact on economic growth.

[11] explored the impact of money supply on economic growth of Nigeria with the help of secondary data during the period of 1981 to 2010 . This study used the following variables such as the real gross domestic product, the real exchange rate, the broad money supply, real interest rate to test the impact of money supply. Eventually, the above study delivered its conclusion that the all 
respective variables were insignificantly impact on the real gross domestic product except the money supply which was statistically significant on the economic growth of Nigeria.

According to the above literatures, there are number of studies which were done internationally about the relationship between the money supply and economic growth. But, in Sri Lankan context, there are no relevant studies. This situation formulates a study gap regarding the relationship between the money supply and economic growth.

\section{Research Methods}

In this section, the following pieces such as variables and data collection, estimation procedures, the specification of econometric model, the autocorrelation test, and the validity of estimated model are discussed:

\section{Variables and data collection}

To achieve the objective of this study, the time series data were utilized which were gathered from the annual reports of the Central Bank of Sri Lanka during the period of 1959 to 2013. In this study, the money supply was considered as key independent variable and the gross domestic product was deemed as the key dependent variable. Other variables were performed as control variables. At this point, the gross domestic product was the proxy variable for the economic growth of Sri Lanka.

In this study, the following variables such as exchange rate, export earnings and inflation rate were considered as control variables. However, most of the literatures in this study used broad money, interest rate, consumer price index as independent variables. But this study is further extended its econometric model using the control variables out of mentioned literatures variables.

\section{Estimation Procedures}

In this study, Ordinary Least Square (OLS) method was employed to test the impact of money supply on economic growth of Sri Lanka because the OLS method was identified as the best linear unbiased estimator (BLUE) and the estimation procedure of this method was easy compared with other econometric estimation procedure. This study deemed the following testing procedures such as the explanation of descriptive statistics of the variables, the specification of econometric model, the autocorrelation testing approach and the validity of estimated model.

\section{Econometric model}

In this study McCallum (1980)'s model was used, because most of the literatures in this study employed this model to test the relationship between the money supply and economic growth. So, this study also consumed McCallum (1980)'s model to test the impact of money supply on economic growth of Sri Lanka using further adding variables. The relationships between explained and explanatory variables were derived into the following function:

$$
G D P_{t}=f\left(M S_{t}, E_{t}, \text { Export }_{t}, \text { Import }_{t}, C C P I_{t}\right)
$$

When this function was converted into the econometric model, it was derived as follows:

$$
G D P_{t}=\beta_{0}+\beta_{1} M S_{t}+\beta_{2} E_{t}+\beta_{2} \text { Export }_{t}+\beta_{2} \text { Import }_{t}+\beta_{3} C C P I_{t}+U_{t}
$$

\section{Where:}

$G D P_{t}$ : Gross domestic product, $M S_{t}$ : Money supply, Ex $x_{t}$ : Exchange rate, Export $t_{t}$ : Exports earnings, Import $t_{t}$ : Imports outflow, $C C P I_{t}$ : Colombo consumer price index, $U_{t}$ : Error term, and $\beta$ was coefficients

After the estimation of the model, the magnitude of parameters and its sign, R- squared and adjusted $\mathrm{R}$-squared, $\mathrm{t}$ - test, and $\mathrm{F}$ - test were utilized to test the partial and overall significance of the variables on the estimated model. Here, the sing and parameters of the variables were used to check the marginal contribution of explanatory variables on explained variable. The $\mathrm{R}$ - squared and adjusted $\mathrm{R}$ - squared were employed to test for the goodness of fit of the estimated regression 
model. The $\mathrm{t}$ - test was applied to check the statistical significance of individual coefficient of variable. While the $\mathrm{F}$ - statistic was utilized to confirm the overall significance of the considered explanatory variables on the explained variable.

\section{Autocorrelation test}

In this study, to test the autocorrelation effect on the estimated model the Durbin - Watson test statistic and the Breusch -Godfrey serial correlation LM test were employed. Moreover, the all data were converted into first difference level to avoid the serial or autocorrelation effect on the estimated model.

\section{Validity of estimated model}

The CUSUM testing approach was used to confirm the validity of the estimated model. The guideline of CUSUM testing approach said that if the line of estimated model was among the CUSUM fixed lines, the estimated model was stable. On the other hand if the line of estimated model was not among the CUSUM fixed lines, the estimated model was not stable.

\section{Results and Discussion}

\section{- Descriptive statistics of the variables}

In descriptive statistics, the numerical positions of each variable are illustrated. The following table demonstrates the position of the variables.

Table 1: The descriptive statistics of the variables

\begin{tabular}{|l|l|l|l|l|l|}
\hline Variables & Mean value & Median & Maximum & Minimum & $\begin{array}{c}\text { Std. } \\
\text { Deviation }\end{array}$ \\
\hline GDP & 3881.045 & 1088.123 & 38580.66 & 507.4327 & 8464.532 \\
\hline MS & 377065.2 & 50860.00 & 3058793 & 1477.00 & 684751.7 \\
\hline Export & 2863.289 & 1395.700 & 10558.80 & 317.900 & 2994.037 \\
\hline Import & 4324.676 & 2051.200 & 20268.80 & 360.600 & 5062.149 \\
\hline CCPI & 1021.402 & 318.2000 & 5416.100 & 103.5000 & 1312.998 \\
\hline Ex. rate & 45.48691 & 29.45000 & 130.5600 & 4.760000 & 42.22300 \\
\hline
\end{tabular}

Source: Estimated from secondary data

In the table 1 , the mean values, the median values, maximum values, minimum values and standard deviations of the considered variables are exposed. When this study compares the descriptive statistics among the variable, the import outflow has high mean value and the exchange rate has low mean value. Likewise, the money supply has high median value and the exchange rate has low median value. The GDP has high maximum value and the exchange rate has low maximum value. The high minimum value is recorded in money supply in the meantime the exchange rate records vary small minimum value. At last the high standard deviation is recorded in the variable of GDP; on the other hand the lowest standard deviation value is recorded in the variable of exchange rate.

\section{- The estimated model:}

Based on the data and its econometric methodology, the following model was estimated and the table 2 demonstrates the results of estimated model.

$$
\begin{gathered}
G D P_{t}=-12967.84+2.44 M S+166.05 \text { Exports }-0.323 \text { Imports }-360.56 C C P I \\
-12622.71 \text { Exchange rate }
\end{gathered}
$$


Table 2: The regression and its results

\begin{tabular}{|l|l|l|l|l|l|}
\hline Variables & MS & Exports & Imports & CCPI & Exchange rate \\
\hline Coefficient & 2.449 & 166.05 & -0.323 & -360.56 & -12622.71 \\
\hline t- statistics & 12.62 & 7.69 & -5.89 & -17.67 & -2.707 \\
\hline p- value & 0.0000 & 0.0000 & 0.0000 & 0.0000 & 0.0094 \\
\hline R- squared $: 92.5289$ & F- statistic : 118.8956 & \multicolumn{3}{|c|}{ DW : 2.430} \\
\hline
\end{tabular}

Source: Estimated from the secondary data

In the table 2, the money supply has positive relationship with the economic growth of Sri Lanka at $1 \%$ significant level. This is confirmed by the coefficient sign of the money supply. Here, the coefficient of the money supply is 2.44 which means if the money supply increases by one million rupees the gross domestic product will be increased by 2.44 million rupees, on the other hand if the money supply will be decreased one million rupees the gross domestic product will be decreased by 2.44 million rupees.

Likewise, other variables [imports, inflation rate, and exchange rate] have preserved the negative relationship on the economic growth of Sri Lanka at 1\% significant level. Here, the coefficient of inflation rate is -360.56 which means if the inflation rate increases by $1 \%$ percent, the gross domestic product decreases by 360.56 million rupees, on the other hand if the inflation rate decreases by one percent, the gross domestic product will be increased by 360.56 million rupees. While the coefficient of imports is -0.323 which means that if the imports increase one million rupees the gross domestic product will be decreased by 0.323 million rupees, conversely if the imports decrease by one million rupees, the gross domestic product will be increased by 0.323 million rupees.

The exports maintain the positive relationship with the economic growth of Sri Lanka at 1\% significant level. The coefficient of exports is 166.05 which mean that if the exports increase by one million rupees the gross domestic product will be increased by 166.05 million rupees on the other hand if the exports earnings decrease by one million rupees the gross domestic product will be decreased by 166.05 million rupees.

Similarly the exchange rate has negative relationship with the gross domestic product and also this variable is significant at $1 \%$ level. The coefficient of this variable is $(-12622.71)$ which means that if the exchange rate increases by one rupee the gross domestic product will be decreased by 12622.71 million rupees on the other hand if the exchange rate decrease by one rupee the gross domestic product will be increased by 12622.71 million rupees.

Meanwhile the R- squared and F- statistics are considered in this study to confirm the overall significance of the estimated model. Here, the $\mathrm{R}$-squared of the estimated model is 0.92 . It means that the independent variables explain 92 percent variation on the dependent variable, Therefore, this model is fitted very well because of the R- squared of estimated model is close to 1.

In the meantime, the F - statistic of this estimated model is 118.89 , it is significant at $1 \%$ level. The F-statistic means that the considered independent variables jointly impact on the dependent variable. Here, the $\mathrm{F}-$ value is high and it is significant at $1 \%$ level. Therefore all the independent variables are simultaneously significant on the economic growth, but individually they are different.

\section{Durbin - Watson test statistic}

In the table 2, the Durbin - Watson test statistic of the estimated model is 2.43 . The guide line says that if the Durbin - Watson statistic of estimated model is closer to the numerical value of 2, the estimated model is not suffering from serial correlation. On the other hand, if the Durbin - Watson statistic of estimated model is less than the numerical value of 2, the estimated model is suffering from serial correlation. Here, the Durbin - Watson statistic of estimated model is 2.43. Therefore, the estimated model is not suffering from serial correlation. 


\section{Breusch -Godfrey serial correlation LM test}

Furthermore, to test the serial correlation impact of the estimated model, the Durbin - Watson testing approach is not enough. Therefore, the Breusch - Godfrey serial correlation LM test is used in addition. The table 3 illustrates the outcome of the Breusch -Godfrey serial correlation LM test.

Table 3: The Breusch -Godfrey serial correlation LM test Breusch-Godfrey Serial Correlation LM Test:

\begin{tabular}{llll}
\hline \hline F-statistic & 1.753553 & Probability & 0.184534 \\
Obs*R-squared & 3.825386 & Probability & 0.147682 \\
\hline \hline
\end{tabular}

Source: Estimated from the secondary data

Consistent with the table 3, the F- statistic of the Breusch - Godfrey serial correlation LM test is 1.753 and its probability value is 0.18 . Likewise, the R-squared of this test is 3.82 and its probability value is 0.14 . Therefore both the $\mathrm{F}$ - statistic and the $\mathrm{R}$ - squared of the Breusch Godfrey serial correlation LM test are greater than at 5\% significant level. The guide line says that if the probability value of both the F - statistic and the R- squared of the Breusch - Godfrey serial correlation LM test are greater than 5\%, the estimated model is not suffering from serial correlation. Therefore, the estimated model is not suffering from the autocorrelation effect. This is proved by the Durbin Watson statistics and the Breusch - Godfrey serial correlation LM test.

\section{Validity of estimated model}

To verify the validity of estimated model, the CUSUM testing approach is employed in this study. The CUSUM shape is shown below:

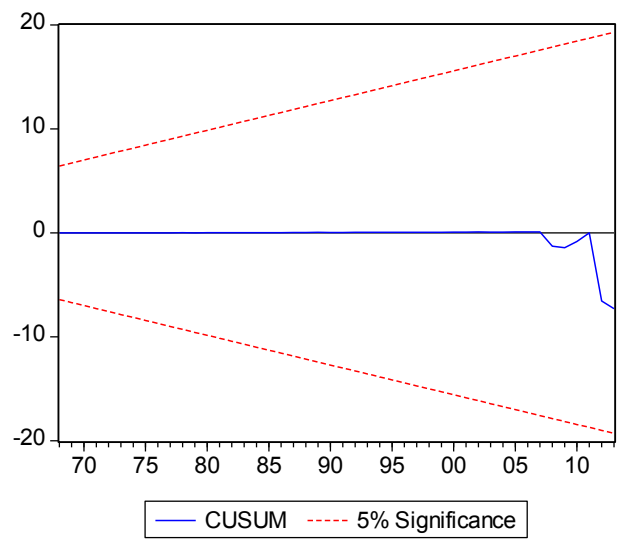

Figure 1: The CUSUM shape of estimated model

The guideline of CUSUM testing approach says that if the line of estimated model is within the CUSUM fixed lines, the estimated model will be stable. On the other hand if the line of estimated model is out of the CUSUM fixed lines, the estimated model is not stable. According to the figure 1 , the fitted line of the estimated model is in the CUSUM fixed two lines. Therefore, this estimated model is valid and can be used to predict in future references.

\section{Conclusion and recommendation}

The objective of the study is to test the impact of money supply on economic growth of Sri Lankan economy. To achieve this objective, the main independent variable in this study is the money supply. Then, the following independent variables such as the inflation rate, the export earnings, the import outflow, the exchange rate are considered as the control variable of this study. On the other hand, the gross domestic product is as dependent variable. According to the estimated model, the 
money supply positively and also significantly impacts on the gross domestic product of Sri Lanka. Therefore, if the authority of money supply increases the money supply, the economic growth of Sri Lanka can be increased. This is confirmed by the empirical results of this study. In future the monetary policy makers of Sri Lanka have to positively consider the money supply as one of the instrument of economic growth of Sri Lanka.

\section{References:}

[1]. A. M.Muhd Zulkhibri, Causality Link between Money, Output and Prices in Malaysia: An Empirical re - examination, 7(1) (2007) 211- 219.

[2]. A. Hossain, Granger Causality between Inflation, Money growth, Currency Devaluation and Economic Growth, International Journal of Applied Econometrics and Quantitative Studies, 2 (3) (2005) 45- 68

[3]. A. L. Mohamed Aslam, S. M. Ahamed Lebbe, The relationship between money stock and economic growth of Sri Lanka: An AEG testing approach, $5^{\text {th }}$ international symposium -2015 at South Eastern University of Sri Lanka (2015) 290-292.

[4]. B. Liu, Empirical research on the relationship among money supply, output and prices, Journal of finance, 29(7) (2002) $10-16$.

[5]. B.T. Macallam, Rational Expectation and Macroeconomic Stabilization Policy, Journal of money, credit and Banking, 12(2) (1980) 716 - 746.

[6]. C. Sims, Money, Income and Causality, the journal of American economic review, America, 63(4) (1972) 540-552.

[7]. E.I. Seoud, M.S. Abou, Testing the relationship between money supply and GDP in Bahrain, International Journal of Economics, Commerce and Management, United Kingdom, II(5) (2014) $1-16$.

[8]. M. Lashkary, B.H. Kashani, the Impact of Monetary Variable on Economic Growth in Iran: A Monetarists' Approach, World Applied Science Journal, 15(3) (2011) 449 - 456.

[9]. M. Nouri, A.J. Samimi, The Impact of Monetary Policy on Economic Growth in Iran, Middle East Journal of Scientific Research, 9(6) (2011) 740 - 743.

[10]. M. S. Ogunmuyiwa, E. Francis, Money supply - Economic growth Nexus in Nigeria, Journal of Social Sciences, 22(3) (2010) $199-204$.

[11]. N. Ikechukwu, The impact of Money Supply on Economic Growth in Nigeria (1981- 2010), Department of economics, Faculty of Management and Social Sciences, Cristias university, Amorji - Nike, Enugu, Nigeria (2012). 